\title{
Two approaches to life in the Second Temple Period: DeUTERONOMY AND QOHOLET
}

Author:

Christo Lombaard ${ }^{1}$

\section{Affiliation:}

${ }^{1}$ Department of Christian

Spirituality, University of

South Africa, South Africa

\section{Correspondence to:}

Christo Lombaard

e-mail:

christolombaard@gmail.

com

\section{Postal address:}

PO Box 392, Unisa,

Pretoria 0003 ,

South Africa

\section{Keywords:}

Old Testament; ethics;

Pentateuch; Qohelet;

Moses

Dates:

Received: 28 Apr. 2009

Date accepted: 17 July 2009

Published: 17 Nov. 2009

How to cite this article:

Lombaard, C., 2009,

'Two approaches to life

in the Second Temple

period: Deuteronomy and

Qoholet', HTS Teologiese

Studies/Theological Studies

65(1), Art. \#185, 4 pages.

DOI: 10.4102/hts.v65i1.185

This article is available

at:

http://www.hts.org.za

\section{Note:}

This paper was originally presented at the Pro Pent Conference, Bass Lake, Pretoria, 30 August 2008.

C) 2009. The Authors. Licensee: OpenJournals Publishing. This work is licensed under the Creative Commons

Attribution License.

\section{ABSTRACT}

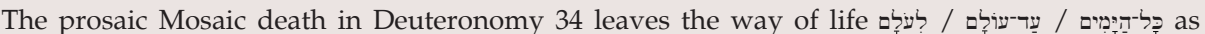

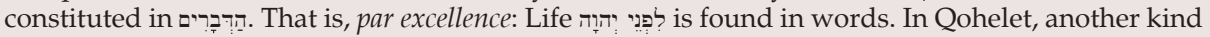
of existentialism, in the face of death, is found, namely in the sensual life of enjoyment of food, drink and companionship. These two approaches constitute different, competing Second Temple period conceptions of how to live, despite death, coram Deo. These two conceptions indicate the existence of more than one ethos within ancient Judaic society - a dynamic often lacking in the South African context.

\section{The 'other hand': A position within the debate on ethics/ethos and the biblical sciences in South Africa}

The recent history in South Africa of the relationship between the disciplines of the biblical sciences and that of theological ethics has not been an altogether uneventful one. When the dogmatician/ethicist Dirkie Smit was asked to write an evaluative conclusion (Smit 1992:303-325) to a collection of essays on biblical ethics by New Testament scholars (Breytenbach \& Lategan 1992), they had not expected to hear what Smit had to say. His harshest criticism related to the methodological presuppositions of the Bible scholars - that they had failed to acknowledge the fundamental distinction between ethos and ethics, that is: between the way things are done, habitually, socio-culturally, reflexively, and the way things ought to be done, evaluated principally and appraised reflectively (Smit 1992:303-317; Smit 1994:287). In addition, a distinction that has been poorly adhered to in the history of South African political readings of the Bible is that between descriptive and prescriptive approaches to and from the Scriptures respectively. Is it, on the one hand, at all possible to read 'lessons for today' or, more directly, 'instructions for today' from biblical texts? On the other hand, would it even be worth the effort analysing the moral sensitivities within these ancient holy texts without seeking in some way to apply insights from such an exegetical exercise to our day?

My choice falls in favour of the second question, the approach sketched as the 'other hand', and in answer to the first question: No, not in any direct manner (what Smit [1992:316] terms deontological and teleological ways, seeking, respectively, norms or laws and purposes or ideals; $c f$. Bosman 1994:262265); but then also, yes: in an analogical, situationally sensitive way (cf. Otto 2004:183-184, and contra e.g. McQuilkin 1989; cf. Smit 1994:287-292), and in open acknowledgement of a host of influences, we may well gain some religious perspectives from biblical texts on/for modern times. Put differently: I opt for a phenomenologically descriptive reading of ethos and, more circumspectly, ethics in the Bible texts (Otto 1994:10); I however (still - cf. Lombaard 2001a:85-86; 2009a) do not think it possible validly to draw directly on such analyses to sustain any current sense of justice or moral outrage.

\section{Cul de sac: The conservative ethical path à la South Africa}

The above is not a popular choice in South Africa, neither in ecclesial nor in political circles (Lombaard 2001b:17-24). Keeping to the former circle: Perhaps the most prominent example in South Africa of using the Bible on political ethics, and doing so directly, was the 1947 volume by Cronjé, Nicol and Groenewald (1947), in which Old and New Testament texts were influentially read as directly affirming the ideology later known as apartheid. This method of the direct appropriation of 'findings' in the Bible to the South African socio-political context was followed in books that supported apartheid (e.g. Du Preez 1959), by church publications that in time sought carefully to distance themselves from this political programme (Kerk en samelewing 1986), and in volumes directly opposing apartheid, such as the Statement by the Institute for Contextual Theology (1991:266-268) and the Kairos Document (1986:18-20) (cf. Mbiti 1986:55; Mosothoane 1978:29; Motlhabi 1987:9-11; Mpumlwana 1993:8). In all cases, the Bible was mined for what was thought it ought to say in favour of 'our cause' - whichever political project that was (cf. Le Roux 1992). However, still, when one indicates the extreme difficulties, up to the point of impossibility, of 'applying' Bible texts to our time (as I did in Lombaard 2006b:144-155), the immediate assumption is made that criticism of Bible usage amounts to rejection of the imperatives/correctnesses of our time.

Within the current South African political climate, with the earlier ( \pm 1990-2005) sense of threat from political leadership on the position of churches and faculties of Theology at universities ( $c f$. Lombaard 2001b:17-19) having subsided, the assumption is now often made that the role of the churches and faculties of Theology is primarily to provide ethical guidance within society. Such moral leadership, it is supposed from the political side, would fall neatly in line with the needs of the current ruling

1.Such an automatic assumption, of course, lays bare the underlying reason for the Bible texts often being drawn upon: in order to provide theological legitimacy to modern concerns. Such a utilitarianism regarding the Bible bears only ventriloquism (a metaphor I first provich

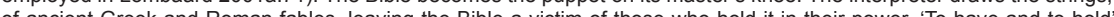
of ancient Greek and Roman fables, leaving the Bible a victim of those who hold it in their power. 'To have and to hold' - a marriage of extreme convenience for such an interpreter, who has the position of power, and hubris. The Scriptures become domesticated (cf. Lombaard 2001a:84-85). Not God, and not the Scriptures, are therefore served; rather, we are.

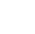


class, namely social stability, by helping to solve the problems of crime, violence, health epidemics and matters related to poverty. Not criticism, debate, questioning analyses or differently minded contributions, but simple adherence to the socio-political programme, is assumed. In this respect, the present South African government is no different from any of its predecessors. Theology, in this line of thinking, is about doing what is right, and Theology is told what the right thing is.

This is an inherently conservative approach to ethics, not to mention to the role of both church and university ( $c f$. Lombaard 2006a:71-84) within society. All these social problems listed are, of course, to be judged negatively (within most ethical systems) and, hence, solutions ought to be sought. Certainly that is the case too now that hardly any Christian theologian of the Western(ised) academy does not subscribe in principle to the theologies of freedom (even if this is done without direct reference to its initiators). However, an approach to ethics that leaves no room for difference, competition, opposition or rejection, does itself not serve freedom: Such an approach to ethics is illiberal repressive, even. The moral trajectory is prescribed. We all must do the good that is expected of us. Ethos rules ethics.

The implication is that doing one's expected duty is good, and developing a supporting philosophy of obedience is almost all that remains. The greater good for the greatest possible number of people, and how to achieve it, has already been decided upon. ${ }^{2}$ Now, theology must become practical, and implement the good. Faiths, churches and faculties of Theology are simply cogs in the wheel of a society already politically decided upon. Ethics becomes ethos operationalised; morality is utilitarian only; thinking is simply functional, not critical, solely implementing accepted truth. Such a scenario is just another 'brave new world' (Huxley [1932] 1994)

It is, however, within precisely such a scenario that analyses of the ethos/ethics we encounter in the Bible done from the 'other hand' can help us, analogically. I will do so differently from my New Testament colleagues in South Africa, who in a followup volume (Van der Watt 2006) took little to no cognisance of the criticisms of Smit, indicated above. ${ }^{3}$ They continue to fall more or less into Hays's category (2006:8-10) of the extraction of ideals or principles for modern behaviour from the biblical texts, whereas I will focus primarily on the implied ethos behind two Old Testament textual bodies. My two texts, chosen for the sake of comparison from within the post-exilic period, are the Moses books and Qohelet, as they relate to the themes of dying and life.

\section{In memoriam: Moses' death and the faithful's life}

We know that Moses did not write the Pentateuch. What we are less sure about is precisely how Moses did not write the Pentateuch. The centuries', but most particularly, the recent decades' competing theories on Pentateuch authorship have proven both these points (Houtman 1994:421-423). The irony should not escape us, though, that it was the death of Moses in Deuteronomy 34 that put the first historical-critical nail in the coffin of uncritical acceptance of Mosaic authorship (Otto 2000a:9; cf. e.g. Deist 1988 and Houtman 1994 for historical

2.The horizons opened up by Nietschean ethics, as reinterpreted recently by Schoeman 2004, are indeed valuable, and will be explored in a subsequent article.

3.The title of this newer volume, Identity, ethics, and ethos in the New Testament certainly hints at Smit's evaluative essay; the essay is, however, only referred to by two of the contributors (most of whom are South African, many of whom contributed to the 1992 volume), and then only very briefly. This is surprising, given the sti Smit caused in 1992, and the sense the title of the 2006 volume gives is that this time round, 'ethics' and 'ethos' will be treated more carefully. However, neither the introduction nor the conclusion to the 2006 volume shows any fundamental reception of Smit's criticisms. His language has been taken over, but not understood: Ethos becomes here merely practical ethics - the application of the rules (about which much optimism is to be found). Smit has not been heard. To a substantial Wxtent (exceptions in ing and then hinting in the traditional South African manner that this implies correct behaviour for us. overviews). This late text, certainly post-exilic (possibly early 3rd century BCE), had the effect, as is the case with all such framing texts, that it cast a pall over the rest of the Moses texts, effectively rendering the whole of the Pentateuch - in the by now familiar metaphor - his epitaph. Although an older kernel of Deuteronomy 34:1-12 may well still reflect earlier folk tales that tried to explain the absence of knowledge of this legendary figure's grave, the implication of appending this epilogue to the Pentateuch, of Moses' divinely orchestrated death and burial (Dt 34:5-6) had direct implications for those in the promised land (Dt 34:1b-4) who held him in such high esteem (Dt 34:8 [\& 12]): The laws of Moses, with which he was most directly associated, were to be kept. Irrespective of the tradition history behind the text (e.g. Coats 1988:148-153 versus Noth 1981:156, 174), now, in the shadow of Moses' death, life - with the clear insinuation: continued life - inside Israel-Juda meant life under holy law. The prosaic Mosaic death in Deuteronomy 34 therefore indicates the way of life as constituted in that is, in the Decalogue and other laws with which the Moses figure had become increasingly identified - to the point that in Deuteronomy 34 direct mention would not be required: The mutual association between Moses and Torah would be strong enough (Britt 2004:167-176).

As an earlier icon (projection, or literary [re]creation) of the religio-political ethos of the 7 th century Jerusalem-based authors, the Moses figure had had a dissident character, namely as guarantor (because of his close encounters with יהוה) of a subtly subversive anti-Assyrian Judean reception of imperial laws (Otto 2000b:43-83, summarised in Otto 2006:35-42). However, during and after the exile, with the Deuteronomistic interpretation of history becoming the dominant theological line of thinking, laws grew to be of prime importance, socially and theologically. To prevent a recurrence of the history of fall from יהוּה, which could result in another tragic cataclysm for Juda/Jerusalem, law became the essence of life. Extra legem nulla salus est. The Moses figure, already associated with laws, and by now a strongly developed unifying figure in the Pentateuch-in-development, therefore remained after the exile an icon representing the Jerusalem ethos - which was however now changed. No longer was Moses a figure of intellectual revolt against Assyria, in favour of יהוָה:; now, Moses has become a mediator of sorts between the new, smaller Israel and יהוֹה, with the latter at that time being the party who was feared (an implication of Deuteronomistic theology). Mosaic law should now guarantee life 'forever' (כָלעד

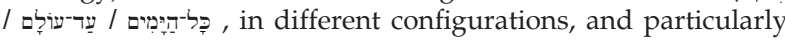
in Deuteronomy). This 'forever', though, has wholly immanent implications, allowing no eschatological or other-/aboveworldly expectations. In the here and now, as all that life is and can be, par excellence life לִפְני יהוָה is found in words of law.

Though, certainly, the pleasures of the body - food, drink, companionship - are acknowledged, even celebrated (also in Nehemiah-Ezra), the dominant force of law is to draw boundaries of appropriateness (e.g. Lv 17-26), for the sake of God's blessing (Ps 1, 19, 94, 119), lest again the wrath of God be incurred.

This is the kind of life the deceased Moses of Deuteronomy 34 bequeaths the followers of his God; formulated from the opposite angle: the kind of ethos of which he had become the icon, postexilicly, extremes of which we see in the books of Nehemiah and Ezra. At the same time, as the reading from the Moses books become an important part of the spirituality of post-exilic Israel (Neh 8:1), so does the further identification of Moses and Torah (cf. Steins 1998:245; תו רת מו שה אשר-צ וּה יה וה את־ישראל), and so does the social insistence on purity.

We know, of course, that competing theologies to this dominant outflow of Deuteronomistic theology are to be found in Second Temple Judaism, for example in books such as Jonah and Ruth. On the social ethos of death and life too, we find a major concurrent view during this period, namely in the book of Qohelet. 


\section{Living life in the face of death: Qohelet's 'theology'}

Somewhat less contested than the Pentateuch, yet with a highly complex oral-literary and culturally-dialogical background, is the book of Ecclesiastes. Here we find a different kind of precisely! (cf. Scheffler 1996:26) - ethos to that sketched above: God is far; life is tough; death is everywhere (cf. Crenshaw 1988:24-25; Spangenberg 1993:23-26). The intense irony of this 'theology' is that the finality of death drives one positively to seize the finality of life (Fischer 1999:18-19, 33-122; Spangenberg 1993:138-139) - carpe diem (an almost inescapable reference here). In Ecclesiastes 2:24-25, 3:12-13, 5:17, 8:15 and 9:7, that is: in a true-to-life chaotic internal patternlessness, and in an intercultural carnival of acceptance-and-rejection of Near Eastern and Mediterranean wisdoms about life (Lohfink 2003:6; Fischer 1999:123-238), a divine(-given) hedonism becomes the ultimate, albeit temporary, expression of life in the face of death. Small wonder that 20th century French existentialists seem to parallel this ethos (Lohfink 2003:14; Scheffler 1996:16-22): Acceptance of the inevitability of death brings forth a paradoxical rebellion a revelling in the (limited) good life has to offer. For Qohelet, though, this defiant existentialism is not because God has died (the initial modern/postmodern move). To the contrary: 'In der Freude offenbart sich Gott' - in momentary fulfilments of the human longing for eternity (Kutschera 1997:372).

This exact point has found an interesting turn in a recent philosophy book in South Africa (Goosen 2007), which - as an unintended latter-day analogous work to that of Qohelet - rejects modernist and postmodernist nihilism in favour of sheer happiness ( $c f$. here too Schoeman 2004). Life, for Goosen (2007:43), is both, and not either, its 'radikale afgrondelikheid' (radical precipitousness) and its 'oneindige eksessiwiteit' (unending abundance). Taking pleasure in the latter moderates the stark finality of the former: Each joyful meal is a sacrament for life, against death. Every delight in food, drink and companionship is an instantaneous eternity ( $c f$. Versfeld 2004), albeit temporary, affirming by this ethos - the ethic of 'living and acting' (Lohfink 2003:114) - that there is life before death: an existential question of at least equal importance to its more popular corollary, on life after death. There is too little of life and too much in it, for us not to have our fill of it. - This forms an apt summary too of the ethos reflected by Qohelet.

\section{Concluding comparatively: Moses versus Qohelet, adversus South Africa's mono-ethicism}

'[Dass man] dem Tod trotzte und dem Leben Raum schuf: das ist höchster Ausdruck einer Ethik, ${ }^{4}$ die aus dem Alten Testament kommt" (Dietrich 2004:145). Such a remark is entirely in keeping with the existential framework of Old Testament anthropology, which does not consider life after death as a human purpose, and hence has to make sense of, that is, find meaning in this life. Rather than a systematic ethic for living this life, the Old Testament covers different historical situations (Barton 1998:14-15; ${ }^{5}$ Hempel 1964:1-6; Mills 2001:1-2), which feed into the ethos of later societies in its reception line, including modern democracies (Schmitt 2004:161; cf. Herms 2004:171-180; Otto 2004:181-188; somewhat dated, Soete 1987; more literary, Goedgebuure 1993). Such dissimilarities of ethos-and-ethics we encounter in the Old Testament hold as true across its historical developments as they do in its contemporaneous variety (Bosman 1994:260; Otto 1994:12).

The latter we briefly looked at in the form of the co-temporaneous, late Second Temple period texts of Qohelet and on Moses' death. The differences between these two are stark:

4.Keeping the opening pages of this paper in mind, I would here substitute 'Ethos' for 'Ethik'.

5.The point made by Barton (1998:14-15) should be well taken: 'Our first impression, that the Old Testament presents its morality [I would prefer: moralities] unsystematically...is misleading if it encourages us to think that it is just a muddle'.
- Moses' death affirms the importance of the law for those who want to remain living in the land of promise. Life ought to be sought in obedience; pleasure is strictly circumscribed. Not keeping to the Torah carries inherently the Deuteronomistic threat of death, like Moses', outside the homeland.

- For Qohelet, death is a given, inescapable for all. It cannot be fled from, and that would equally be the case in exile or in Juda. Even great kingdoms that come, go too... Hence, God gives the bodily pleasures of life - food, drink, sex, companionship - as the sensuous affirmation of being, over and against ceasing to be. Pleasing God entails not a life of abiding by laws, but of exploring joys. God's benevolence works not through obedience, but through experience.

The value of acknowledging these two competing ways of life within the same 3rd century BCE Jewish faith is that naïve assumptions on there being only one possible 'right' way of living are undermined. Even if done in a very brief (further investigations into these texts soon show more differences) and limited (many more texts, each reflecting an own ethos, could be studied) manner, such as the case is here, the idea of only one ethic (system of thinking) and only one ethos (manner of living) is shown to be flawed.

However, South African society and its theological leaders like to call on the Bible in socio-political debate, often based on the assumption that their viewpoints on a just society would be found there, exclusively (Lombaard 2001a:69-87; cf. Lombaard 2009b:89-93). All such an approach does, illiberally, is to ignore the diversity that does exist in society, in favour of uncritical power play. Even though it can be said in very broad terms that '[w] as das AT von Gott sagt, ist vom Anfang bis zum Ende vom Handeln und Reden Gottes bestimmt' (Westermann 1997:393), the implications this had for the faithful of Israel, for the church through the ages and still for those who in our day draw on the 'Good Book', is by no means unilinear (Westermann 1997:399400).

\section{REFERENCES}

Barton, J., 1998, Ethics and the Old Testament, SCM Press, London.

Bosman, H.L., 1994, 'Problems and prospects of the theologicalethical interpretation of the Old Testament', Old Testament Essays 7(4) (special edition), 259-266.

Breytenbach, C. \& Lategan, B. (eds.), 1992, 'Geloof en opdrag: Perspektiewe op die etiek van die Nuwe Testament', Scriptura (special edition S9a), 303-325.

Britt, B., 2004, Rewriting Moses: The narrative eclipse of the text, T\&T Clark International, London.

Coats, G.W., 1988, Moses: Heroic man, man of God (JSOT suppl. 57), JSOT Press, Sheffield.

Crenshaw, J.L., 1988, Ecclesiastes: A commentary, SCM Press, London.

Cronjé, G., Nicol, W.M. \& Groenewald, E.P., 1947, Regverdige rasseapartheid, Die Christen-studenteverenigingmaatskappy van Suid-Afrika, Stellenbosch.

Deist, F., 1988, Mosaic of Moses, NG Kerkboekhandel, Cape Town.

Dietrich, W., 2004, 'Einführung (Unterteil, Crüsemann, F, Dietrich, W \& Schmitt, H-C Gerechtigkeit - Gewalt Leben. Was leistet einen Ethik des Alten Testaments?)', in B.M. Levinson \& E. Otto (Hrsg.), Recht und Ethik im Alten Testament (Altes Testament und Moderne, Band 13), pp. 145146, LIT Verlag, Münster.

Du Preez, A.B., 1959, Eiesoortige ontwikkeling tot volksdiens. Die hoop van Suid-Afrika, HAUM, Cape Town.

Fischer, S., 1999, Die Aufforderung zur Lebensfreude im Buch Kohelet under seine Rezeption der ägyptischen Harfnerlieder (Wiener Alttestamentliche Stdien, 2), Peter Lang, Frankfurt am Main.

Goedgebuure,J.,1993,De Schrift herschreven: Debijbel in demoderne literatuur, Amsterdam University Press, Amsterdam.

Goosen, D., 2007, Die nihilism: Notas oor ons tyd, Praag, Pretoria. 
Hays, R.B., 2006, 'Mapping the field: Approaches to New Testament ethics', in J.G. van der Watt (ed.), Identity, ethics, and ethos in the New Testament, pp. 3-19, Walter de Gruyter, Berlin.

Hempel, J., 1964, Das Ethos des Alten Testaments, 2nd edn., (BZAW 67), Verlag Alfred Töpelmann, Berlin.

Herms,E., 2004, 'Die Gegewenwartsbedeutung von Daseinsverständnis und Ethos der Bibel, besonders des Alten Testament', in B.M. Levinson \& E. Otto (Hrsg.), Recht und Ethik im Alten Testament (Altes Testament und Moderne, Band 13), pp. 171-180, LIT Verlag, Münster.

Houtman, C., 1994, Der Pentateuch: Die Geschichte seiner Erforschung neben einer Auswertung, Kok Pharos Publishing House, Kampen.

Huxley, A., [1932] 1994, Brave new world, Flamingo, London.

Institute for Contextual Theology, 1991, in L. Alberts \& F. Chicane (eds.), The road to Rustenburg: The church looking forward to a new South Africa, pp. 266-268, Struik Christian Books, Cape Town.

Kairos Document. Challenge to the church, 1986, rev. 2nd edn., Skotaville Publishers, Braamfontein.

Kerk en samelewing: 'n Getuienis van die Ned. Geref. Kerk soos aanvaar deur die Algemene Sinode van die Ned. Geref. Kerk, 1986, Algemene Sinodale Kommissie, Bloemfontein.

Kutschera, F., 1997, 'Kohelet: Leben im Angesicht des Todes', in L. Schwienhorst-Schönberger (Hrsg.), Das Buch Kohelet: Studies zur Struktur, Geschichte, Rezeption und Theologie, pp. 363-376, Walter de Gruyter, Berlin.

Le Roux, J.H., 1992, Whose side is God on? / Aan wie se kant is God?, CB Powell-Bybelsentrum, University of South Africa, Pretoria.

Lohfink, N., 2003, Qoholet: A continental commentary, Fortress Press, Minneapolis.

Lombaard, C., 2001a, 'The Bible in the apartheid debate', in J.W Hofmeyr, C.J.S. Lombaard \& P.J. Maritz (eds.), $1948+50$ years. Theology, apartheid and church: Past, present and future (Perspectives on the Church / Perspektiewe op die Kerk, series 5: vol. 1), pp. 69-87, IMER (Institute for Missiological and Ecumenical Research), University of Pretoria, Pretoria.

Lombaard, C., 2001b, 'The left governing hand and the right governing hand: Begging for a church without public hands?' Journal of Theology for Southern Africa 109, 17-24.

Lombaard, C., 2006a, 'There is rebellion afoot, and revelry: The nascent reformation of intellectual integrity within South African universities', Education as Change 10(1), July, 71-84.

Lombaard, C., 2006b, 'The relevance of Old Testament science in/for Africa: Two false pieties and focussed scholarship', Old Testament Essays 19(1), 144-155.

Lombaard, C., 2009a (forthcoming), 'Does contextual exegesis require an affirming Bible? Lessons from 'apartheid' and 'Africa' as narcissistic hermeneutical keys', Scriptura 99, n.p.

Lombaard, C., 2009b, 'The fall of the Berlin wall and the end of apartheid South Africa', in K. Koschorke (ed.), Falling walls. The year 1989/90 as a turning point in the history of world Christianity [Einstürzende Mauers. Das Jahr 1989/90 als Epochenjahr in der Geshichte des Weltchristentums], pp. 89-93, Harrassowitz Verlag, Wiesbaden.

Mbiti, J.S., 1986, Bible and theology in African Christianity, Oxford University Press, Nairobi.

McQuilkin, R., 1989, An introduction to biblical ethics, Tyndale House, Wheaton

Mills, M.E., 2001, Biblical morality: Moral perspectives in Old Testament narratives, Ashgate, Aldershot.

Mosothoane, E.K., 1978, 'The use of Scripture in black theology', in W.S. Vorster (ed.), Scripture and the use of Scripture, pp. 28-37, University of South Africa, Pretoria.
Motlhabi, M.B.G., 1987, 'Liberation Theology: An introduction', in P.G.R. de Villiers (ed.), Liberation Theology and the Bible, pp. 1-14, University of South Africa, Pretoria.

Mpumlwana, M.M., 1993, 'The road to democracy: The role of contextual theology', Journal of Theology for Southern Africa 85(Dec), 5-18.

Noth, M., 1981, A history of Pentateuchal traditions, Scholars Press, Atlanta.

Otto, E., 1994, Theologische Ethik des Alten Testaments, W. Kohlhammer, Stuttgart.

Otto, E., 2000a, 'Der historische, der biblische und der historisch-kritische Mose. Probleme ihrer Relation und Wirkungsgeschichte', in E. Otto (ed.), Mose: Ägypten und das Alte Testament, pp. 9-16, Verlag Katholisches Bibelwerk, Stuttgart.

Otto, E., 2000b, 'Mose und das Gesetz: Die Mose-Figur als Gegenentwurf Politischer Theologue zur neuassyrischen Königsideologie im 7. Jh. v. Chr.', in E. Otto (ed.), Mose: Ägypten und das Alte Testament, pp.43-83, Verlag Katholisches Bibelwerk, Stuttgart.

Otto, E., 2004, 'Wer wenig im Leben hat, soll viel im Recht haben: Die kulturhistorische Bedeutung der Hebräischen Bibel für eine moderne Sozialethik', in B.M. Levinson \& E. Otto (eds.) Recht und Ethik im Alten Testament (Altes Testament und Moderne, Band 13), pp. 181-188, LIT Verlag, Münster.

Otto, E., 2006, Mose: Geschichte und Legende, Verlag C.H. Beck München.

Scheffler, E.H., 1996, Prediker se positiewe raad (professorial inaugural address), University of South Africa, Pretoria.

Schmitt, H-C., 2004, 'Leben (Unterteil, Crüsemann, F, Dietrich, W \& Schmitt, H-C Gerechtigkeit - Gewalt - Leben. Was leistet einen Ethik des Alten Testaments?)', in B.M. Levinson \& E. Otto (Hrsg.), Recht und Ethik im Alten Testament (Altes Testament und Moderne, Band 13), pp. 161-165, LIT Verlag, Münster.

Schoeman, M., 2004, Generositiet en lewenskuns: Grondtrekke van 'n post-Nietscheaanse etiek, Fragmente Uitgewers, Pretoria.

Smit, D., 1992, 'Oor "Nuwe-Testamentiese etiek", die Christelike lewe en Suid-Afrika vandag', in C. Breytenbach \& B. Lategan (reds.), Geloof en opdrag: Perspektiewe op die etiek van die Nuwe Testament, Scriptura (special edition S9a), 303-325.

Smit, D.J., 1994, 'The future of Old Testament studies in South Africa: An ethicist's perspective', Old Testament Essays 7(4) (special edition), 286-292.

Soete, A., 1987, Ethos der Rettung - Ethos der Gerechtigkeit, Echter Verlag, Würzburg.

Spangenberg, I.J.J., 1993, Die boek Prediker, NG Kerk-Uitgewers, Cape Town.

Steins, G., 1998, 'Die Bücher Esra und Nehemia', in E. Zenger (ed.), Einleitung in das Alte Tesament, 3rd edn., pp. 234-245, Verlag W. Kohlhammer, Stuttgart.

Tolmie, D.F., 2006, 'Liberty - love - the Spirit: Ethics and ethos according to the letter to the Galatians', in J.G. van der Watt (ed.), Identity, ethics, and ethos in the New Testament, pp. 241255, Walter de Gruyter, Berlin.

Van der Watt, J.G. (ed.), 2006, Identity, ethics, and ethos in the New Testament, Walter de Gruyter, Berlin.

Versfeld, M., 2004, Food for thought: A philosopher's cookbook, 3rd edn., Double Storey Books, Cape Town.

Westermann, C., 1997, 'Gottes Handeln und Gottes Reden im Alten Testament', in H.T.C. Sun \& K.L. Eades (eds.), Problems in Biblical Theology: Essays in honor of Rolf Knierim, pp. 389403, Williem B Eerdmans, Grand Rapids. 